\title{
Zinc Oxide Nano Particle (ZnO NPs) and Innate Immunity: New Perspectives in Immunotoxicity
}

\author{
Jitendra Kumar ${ }^{1}$, Kavita Rani $^{1}$, Sonia $\operatorname{Sangwan}^{2}$, M.D Mitra ${ }^{3}$, \\ H.B Singh ${ }^{4}$, H.P Yadav ${ }^{5}$ and Gautam Kaul ${ }^{1}$
}

${ }^{1}$ Animal Biochemistry Division, ICAR-National Dairy Research Institute, Karnal (Haryana)-13200, India

${ }^{2}$ Dairy Chemistry Division, ICAR- National Dairy Research Institute, Karnal (Haryana)-132001, India

${ }^{3}$ Department of Chemistry, IIT-Banaras Hindu University (BHU), Varanasi-221005, Uttar Pradesh, India

${ }^{4}$ Department of Chemistry, IIT-Delhi, Delhi-110016, India

${ }^{5}$ Veterinary Gynecology and Obstetrics Division ICAR-National Dairy Research Institute, Karnal (Haryana)-132001, India

*Corresponding author

\section{A B S T R A C T}

In the contemporary, application of zinc oxide nanoparticles ( $\mathrm{ZnO} \mathrm{NPs})$ is growing exponentially in the food industry and allied sciences. Hence the public concern about

\section{Keywords}

Zinc oxide nanoparticle, Macrophages, Nitric oxide, Immunotoxicity, Phagocytosis

Article Info

Accepted:

15 June 2018

Available Online:

10 July 2018 their potential adverse effect is increasing. ZnO NPs with their unique physiochemical properties are thought to underlie their exploitable immunological activities. A study was conducted to investigate the effects of $\mathrm{ZnO}$ NPs with innate immune cells. To achieve this aim, amongst three experimental groups, two groups received (5.0 and 50 $\mathrm{mg} / \mathrm{kg} \mathrm{b.w),} \mathrm{ZnO} \mathrm{NPs} \mathrm{was} \mathrm{dispensed,} \mathrm{subsequent} \mathrm{analysis} \mathrm{of} \mathrm{the} \mathrm{body,} \mathrm{and} \mathrm{different}$ organs weight, cytotoxicity were done using (3-(4, 5-Dimethylthiazol-2-yl)-2, 5diphenyl-tetrazolium bromide (MTT), Water-soluble tetrazolium salts (WST), Nitric oxide (NO), phagocytosis. The levels of NO yield, phagocytosis, and weight of spleen increased $(* \mathrm{P}<0.05)$ due to $\mathrm{ZnO}$ NPs at a dose of $50 \mathrm{mg} / \mathrm{kg}$ b.w, which harmed the functionality of macrophages. $\mathrm{ZnO}$ NPs may release $\mathrm{Zn}^{2+}$ ions and producing reactive oxygen species and caused dose-dependent toxicity. The results demonstrate that the high dose of $\mathrm{ZnO}$ NPs caused toxicity which is the analysis by body and liver, kidney, and spleen weight, cell viability (MTT, WST), nitric oxide (NO) level, and phagocytosis assay. The levels of NO production, phagocytic activity, and spleen weight increased significantly $(* \mathrm{P}<0.05)$ while a decrease in NO production and phagocytosis was observed. ZnO NPs $(5.0 \mathrm{mg} / \mathrm{kg}$ b.w) caused significantly increased phagocytosis, therefore high at dose $\mathrm{ZnO}$ NPs caused immunocytotoxicity. 


\section{Introduction}

Nanotechnology is an emerging technology, which can lead to a new revolution in every field of science (Rico et al., 2011), and widely used in different areas of science. Nanomaterials have become an essential part of our day to day lives because of their special properties including small size, high specific surface area and reactivity. Nanoparticles (NPs) have peculiar physiochemical properties and used in different fields such as in industrial catalyst, nanomedicine (Meng et al., 2012), sensors, nanofertilizer (Lopez-Moreno et al, 2010), diagnostic imaging tools in health sectore (Yoo et al., 2011). However, safety level knowledge about biological effects (immunological), potential health risks and toxicities of the widely exposure to nanomaterials still remain unclear.

Zinc Oxide nano particle ( $\mathrm{ZnO}$ NPs) may enter the human as well as the animal body via food chain or directly ingestion of food items, inhalation, drugs, and nano vaccine or through the skin cosmetics and sun cream 'Wang et al., 2007). Once entered in body systems, they circulate in biological milieu, consequently come into contact with different of biomolecules including proteins and lipids as well dissolve in the body fluids such as blood, lymph and interstitial fluids. The biological molecules immediately coat the surface of Zinc Oxide nano particle ( $\mathrm{ZnO} \mathrm{NPs}$ ) and form "corona" (Lundqvist et al., 2011), which dictate the biological uniqueness of the $\mathrm{ZnO}$ NPs (Lynch et al., 2008) and phagocytes through Innate immune cells include mononuclear phagocytes (monocytes, macrophages, and dendritic cells), granulocytes (neutrophils, eosinophils, basophils) and other cells. Mononuclear phagocytes, first identified by Metschnikoff over 100 years ago, are present in all adult mammalian tissues and play key roles in host defence system. However, acute or prolonged use of $\mathrm{ZnO}$ NPs in different consumer materials, drugs and cosmetics items my produce severe impediment of immunity (Peng XH, Qian X, Mao H et al., 2008). ZnO NPs affinity with macrophages depends upon interaction with bio molecules and chemical instability. Most important evidence implies that the toxicity of ZnO NPs could be affected by size and/or electrostatic charge or dose. ZnO NPs immunotoxicity was defined by the dose of $\mathrm{ZnO}$ NPs that produced a $50 \%$ reduction of cell viability (Puzyn et al., 2011). Instability of the ZnO NPs is quantified as the enthalpy of formation of a gaseous cation $\left(\Delta \mathrm{H}_{\mathrm{ME}+}\right)$ that had the same oxidation state (charge) as the nanoparticles (NPs) solid state (Puzyn et al., 2011). The relationship between cytotoxicity and $\mathrm{ZnO}$ NPs instability $\left(\Delta \mathrm{H}_{\mathrm{ME}+}\right)$ was defined as

$\log \left(1 / \mathrm{EC}_{50}\right)=2.59-0.50 * \Delta \mathrm{H}_{\mathrm{ME}+}$

Where, $\mathrm{EC}_{50}$ is the dose of nanoparticle that gives half-maximal response and $\left(\Delta \mathrm{H}_{\mathrm{ME}+}\right)$ is the NPs instability. Instability directly related to reactivity of nanoparticle with biological molecules and corona formation. Small size nanoparticle is more reactive because of high surface area to volume ratio. Zinc oxide nanoparticle ionize to form $\mathrm{Zn}^{2+}$ ions; positive charged $\mathrm{ZnO}$ NPs could be more toxic then negative charge nanoparticles due to more interaction with the negative charge of acidic acid (sialic acid) on the surface of macrophages (Dwivedi et al., 2009). Number of cationic charge on the nanoparticle is inversely proportional to the cytotoxicity of $\mathrm{ZnO}$ NPs. When nanoparticle enters inside the body, absorbed and translocates to tissues and, as like any foreign substance, is likely to encounter the innate immune system. Inflammation is the first immune response produced by innate immune system. The inflammatory process begins by innate immune cells present in all tissues mainly resident as macrophages, dendritic cells, 
neutrophils and mast cells. Nanoparticles produce a many of chemical factors that induce vasodilatations and favor chemo taxis of phagocytes. $\mathrm{ZnO}$ NPs generate reactive oxygen species (ROS) when interact with immune cells causes accumulation of oxidized glutathione (GSSG). The amount of the generated oxidative stress determines the pathogenicity or cell death of nanoparticle (Nel et al., 2006).

Withaferin A was the first withanolide to be isolated from Withaferin A (Glotter, 1991; Kupchan et al., 1965). Withaferin A is mainly present in roots, leaves, and stems, of $W$. somnifera and accounts for about $1.6 \%$ of the dry weight (Gupta et al., 1996; Mirjalil et al., 2009). Withaferin A is more reactive because of ketone presenting different rings, unsaturated A ring, the epoxide in B ring and unsaturated lactone ring. It was shown to have anti-inflammatory, antitumor, anti-stress, antioxidant, immuno-modulatory, hematopoietic, and rejuvenating properties as well as benefiting the endocrine, cardiopulmonary, and central nervous systems (Mishra et al., 2008). In this study, we explored the in vivo immunotoxicity of $\mathrm{ZnO}$ NPs on peritoneal macrophages, and effect of $\mathrm{ZnO}$ NPs on the functionality of macrophages using Balb/c mice. Further, we investigated the Competency of Withaferin A on immunotoxicity.

\section{Materials and Methods}

All chemicals were purchased from Sigma and Aladdin reagent Company

\section{Preparation ZnO NPs suspensions}

Zinc oxide Nanoparticle (Cat.Nr.PL-ZnO-25$25 \mathrm{~g}$ ) was purchased from the Plasma Chem. GmbH Rudower Chaussee 29, D-12489, Berlin (Germany). The ZnO NPs used in this study were sized at $25 \mathrm{~nm}$ (240 mg and 2400 mg dry powder of $\mathrm{ZnO}$ NPs was dissolved into $14.4 \mathrm{~mL}$ reverse osmosis (RO) water for dose 5.0 and $50 \mathrm{mg} / \mathrm{kg}$ body weight respectively. The $\mathrm{ZnO} \mathrm{NP}$ suspension was Vortexed for 5 minutes at room temperature and then kept at room temperature until use. Before using, the suspension was sonicated at $4{ }^{0} \mathrm{C}$ for10-15 minutes with a sonicator (Branson Sonic Power Company, Danbury).

\section{Particle characterization}

The suspension of $\mathrm{ZnO}$ NPs in RO water was sonicated (Branson Sonic Power Company, Danbury) for $10 \mathrm{~min}$. The hydrodynamic diameter was determined by Zeta sizer NanoZS (Malvern instruments Ltd., Malvern, UK). The average size of $\mathrm{ZnO}$ NPs $(100 \mu \mathrm{g} / \mathrm{mL})$ in Milli-Q water was determined by transmission electron microscopy (TEM). (Tale1)

\section{Maintenance of animals and treatment}

Six-week-old Male Balb/c mice, supplied by the laboratory animal house, CSIR-Indian institute of integrative medicine, Jammu, India were used in this study $(n=6)$. The initial body weight $25 \pm 1.5 \mathrm{~g}$ (mean \pm standard error of mean, SEM) of mice were housed at room temperature (22-25 $0 \mathrm{C}$ in a $12 \mathrm{hr}$ light and 12$\mathrm{hr}$ dark period with an adlibidum feed and RO (drinking) water and were maintained in a pathogen-free condition. The animals for the research have been approved by institutional ethical committee, ICAR-NDRI, Karnal 132001, India.

\section{Experimental design and Grouping of animals}

Balb/c mice were divided into three groups with six animals each (Table 2). Normal control group and which given $\mathrm{RO}$ water and two experimental groups were treated with two doses of $\mathrm{ZnO}$ NPs. The $\mathrm{ZnO} \mathrm{NP}$ suspension was orally administered in the 
Balb/c mice with the dosage of $5 \mathrm{mg} / \mathrm{kg}$ and $50 \mathrm{mg} / \mathrm{kg}$ alone, every day continuously for 28 days. All experiments were approved by the Institutional Animal Institutional Ethical Committee, ICAR-NDRI, Karnal 132001, India.

The animals were administered with Zinc oxide nanoparticle (ZnO NPs) $5.0 \mathrm{mg} / \mathrm{kg}$ b.w and $50 \mathrm{mg} / \mathrm{kg}$ b.w to investigate the effect of $\mathrm{ZnO}$ NPs on macrophage functionality. After 28 days of administration, animals were euthanized and the peritoneal fluid was collected in fresh DMEM media for experiment and different organs were collected in PBS for organ index measurement.

\section{Collection of peritoneal fluid}

The Balb/c mice were euthanized by diethyl ether and the peritoneal fluid was collected by injecting $6 \mathrm{~mL}$ of DMEM Hams F-12 medium (without phenol red) in peritoneal cavity by following a gentle massage of the abdomen (Perdigon et al., 1986). A portion of the peritoneal exudates cell suspension was used for MTT assay and WST assay. The cells in peritoneal fluid were counted using Neuters' chamber and $1 \times 10^{6}$ cells/ $\mathrm{mL}$ was taken further.

\section{Evaluation of macrophage functions}

$\mathrm{Balb} / \mathrm{c}$ peritoneal macrophage was cultured in chemically define Dulbecco's Modified Eagle's Medium Hams F-12 DMEM; (SigmaAldrich, St Louis, MO, USA) without phenol red, supplemented with $1.2 \mathrm{~g} / \mathrm{L}$ of sodium bicarbonate, $0.1 \%$ bovine serum albumin followed by addition of penicillin (200U/ mL) and streptomycin $(50 \mu \mathrm{g} / \mathrm{mL})$. The $\mathrm{pH}$ of the medium was adjusted to 7.2 using $1.0 \mathrm{~N} \mathrm{HCl}$ or $\mathrm{NaOH}$ and then sterilized by passing through $0.2 \mu \mathrm{m}$ Millex-GV filter unit (Millipore).
Isolation and enrichment of macrophages(in vitro culture)

The remaining portion of peritoneal fluid was distributed into $35 \mathrm{~mm}$ culture grade petri dishes and incubated in a humidified atmosphere of $5 \% \mathrm{CO}_{2}$ in air at $37{ }^{\circ} \mathrm{C}$ for $2 \mathrm{~h}$ to allow attachment of adherent cells according to Kumangi, 1979. Non-adherent cells were removed by washing two times with DMEM. The adherent cells were collected by jetting chilled $1 \mathrm{ml}$ DMEM onto the cells with a pipette and cells were counted again using neubeur's chamber under phase contract microscope and final concentration was adjusted to $1.0 \times 10^{6}$ cells/ mL

\section{Macrophage culture (in vitro)}

One fraction of above enriched macrophages were cultured in DMEM Hams F-12 medium and incubated in a humidified atmosphere of 5 $\% \mathrm{CO}_{2}$ for $18 \mathrm{~h}$ at $37{ }^{\circ} \mathrm{C}$. At the end of the incubation period, phagocytosis assay was done. Other fraction of enriched macrophages $\left(5 \times 10^{5}\right.$ cells $\left./ \mathrm{ml}\right)$ suspended in DMEM supplemented with heat-inactivated Fetal calf serum 10\% (FBS, Hyclone Laboratories Inc.), were plated $300 \mu \mathrm{l} /$ well in 24 well cell culture plates in presence of $E$. coli (serotype 055:B5) lipopolysaccharide (LPS) $(1 \mu \mathrm{g} / \mathrm{ml}$ final concentration) and incubated in $\mathrm{CO}_{2}$ incubator perfused with $5 \% \mathrm{CO}_{2}$ in air at $37{ }^{\circ} \mathrm{C}$ for $24 \mathrm{~h}$. The cell free supernatant collected at $24 \mathrm{~h}$ was analyzed for NO (nitric oxide) production.

\section{Study of macrophage viability}

\section{MTT (3-(4, 5-Dimethylthiazol-2-yl)-2, 5- diphenyl-tetrazoliumbromide) assay}

The MTT assay was employed to evaluate the cytotoxic effect of ZnO NPs. The MTT assay was done according to Mosman., 1983, with some modifications. Peritoneal macrophages were isolated from the peritoneal fluid of mice 
in 96-well plates $\left(1.0 \times 10^{6}\right.$ macrophage/well), $10 \mu \mathrm{MTT}(5.0 \mathrm{mg} / \mathrm{ml})$ reagents was added per well, then incubated for $4 \mathrm{~h}$ at $37{ }^{\circ} \mathrm{C}$ humidified incubator with $5 \% \mathrm{CO}_{2}$. The cells were removed from incubator and $100 \mu \mathrm{l}$ DMSO (dimethyl sulfoxide) was added to it. After 10 minutes, Absorbance (A) of plate was read by an ELISA reader at $570 \mathrm{~nm}$. (Beckman Coulter, Fullerton, CA, USA). The percentage of cell viability was calculated by the following formula Macrophage cell viability $(\%)=$ (mean absorbency in test wells)/ (mean absorbency in control wells) $\times 100$. The viability of the macrophages used in all the experiments was higher than $98 \%$, as measured by the $0.4 \%$ trypan blue exclusion method

\section{Nitric oxide assay}

This assay was done for measurement of nitric oxide (NO). Nitric oxide production in the peritoneal macrophages culture medium was quantified spectrophotometrically using the Griess reagent G4410-10G. The nitrite $\left(\mathrm{NO}_{2}{ }^{-}\right)$ present in the supernatant of culture macrophages $\left({ }^{M \phi}\right)$ was used as an indicator of NO. Nitrite is a stable degradation product of NO. Nitric oxide (NO) production was determined by measuring the stable endproducts of NO metabolism i.e. nitrite and nitrate. Nitrate present in the sample was reduced to nitrite using vanadium chloride, which was then estimated using Griess reagent.

Total nitric oxide production was determined by the method of Miranda et al., 2001. Briefly, $100 \mu \mathrm{l}$ of vanadium chloride and $50 \mu \mathrm{l}$ of Griess reagent were added to $100 \mu \mathrm{l}$ cultures supernatant and incubated at $37{ }^{\circ} \mathrm{C}$ for $40 \mathrm{~min}$. The absorbance was measured at $550 \mathrm{~nm}$ and the concentration of nitrite (indicator of nitric oxide) was determined from the standard curve generated from serial dilutions of $\mathrm{NaNO}_{2},(3.12 \mu \mathrm{M}$ in DMEM).

\section{Macrophages phagocytosis assay}

Phagocytosis is a two stage process involving binding (adherence) of foreign particle to macrophage followed by ingestion of the former by the later. Yeast were dissolved in DMEM media and sonicated gently to disrupt clumps and further diluted to $1.0 \times 10^{8}$ cells/mL. For phagocytosis assay peritoneal fluid $\left(1 \times 10^{6}\right.$ cells $\left./ \mathrm{mL}\right)$ were incubated at $37{ }^{0} \mathrm{C}$ for $2 \mathrm{~h}$ in $35 \mathrm{~mm}$ Petri-dishes. The medium was removed and the adhered cells were washed twice with DMEM Hams F-12. Then $1 \mathrm{ml}$ of DMEM and $100 \mu \mathrm{l}$ of yeast cells $\left(1 \times 10^{8}\right.$ cells $\left./ \mathrm{ml}\right)$ was added and incubated for $1 \mathrm{~h}$ at $37{ }^{\circ} \mathrm{C}$. The supernatant was removed; the cells were washed with DMEM and air dried. The cells were then stained with May Grunwald stain freshly diluted with Giemsa buffer (1:2) for $2 \mathrm{~min}$ and then washed with PBS and dried. Phagocytosis was observed at 1000X magnification under oil immersion microscope (Olympus Optical Co. Ltd, Japan) and following observations were recorded.

Phagocytosis $(\%)=$ No of macrophages with yeast cells internalized (N) per 100 Macrophages

\section{Evaluation of phagocytic activity of macrophages}

The phagocytic activity of macrophages was evaluated by counting phagocytic cells (macrophages) after their identification on Neubauer Chamber, stained with $0.4 \%$ trypan blue. A minimum of 100 phagocytic cells were counted in each field, together with the number of ingested yeast beads, using a 1000 $\mathrm{X}$ magnification under oil immersion microscope (Olympus Optical Co. Ltd,. The percentage $(\%)$ of macrophages showing phagocytic activity and the number of yeast contained within macrophages cells was determined. Phagocytic activity was expressed as phagocytic index (PI), calculated using the following formula (Barbuddhe et al., 1998) 


\section{Statistical analysis}

In this study, all data are presented as the mean \pm standard error mean. The mean values among different groups were analyzed and compared using one-way analysis of variance (ANOVA) followed by subsequent multiple comparison test (Tukey) with Graph Prism (Graph Pad Software, La Jolla, CA, USA) version 5 software packages. One-way ANOVA with repeated measurements followed by Tukey's test was applied to test the influence of $\mathrm{ZnO}$ NPs on bodyweight gain, spleen weight, cell viability, phagocytosis $\%$, nitric oxide production, and relative mRNA expression. A $P \leq 0.05$ and $P \leq 0.1$ was considered to be statistically significant.

\section{Results and Discussion}

\section{ZnO-NPs Characterization}

The average particle size of $\mathrm{ZnO}$ NPs measured by dynamic light scattering (DLS) were $52.80 \mathrm{~nm}$ (Table 1 and Fig. 1) while manufacture size was $25 \mathrm{~nm}$. ZnO NPs structure was spherical.

\section{Effects on body and organ weight gain study}

The effect of $\mathrm{ZnO}$ NPs on the body and organ weight was examined by weighing balance. $\mathrm{ZnO}$ NPs at the dose $5.0 \mathrm{mg} / \mathrm{kg} \mathrm{b.w}$ and 50 $\mathrm{mg} / \mathrm{kg}$ b.w had no effect on the body, liver, and kidney weight after 28 day of exposures. Although there was a significant increase in the spleen weight at a dose $50 \mathrm{mg} / \mathrm{kg} \mathrm{b.w.} \mathrm{A,}$ increased the spleen weight $(\mathrm{P}<0.05)$ compared to the $\mathrm{ZnO}$ NPs $50 \mathrm{mg} / \mathrm{kg}$ group (Fig. 2).

\section{Assessment of macrophages viability}

The cell viability assessment was done by MTT and WST assay to evaluate the cytotoxicity of $\mathrm{ZnO}$ NPs in Macrophages. When mice were treated with various concentrations of ZnO NPs (5.0 and $50 \mathrm{mg} / \mathrm{kg}$ body weight) for 28 days, macrophages viability was significantly influenced as compared to control. The effect on viability in $\mathrm{Balb} / \mathrm{c}$ mice macrophages is shown in Table 3, 4 and Figure 3.

\section{Nitric oxide assay}

Nitric oxide (NO) is a reactive form of nitrogen and is an important cellular signaling molecule involved in different biological processes, and moreover, serves as one of the key mediators of immune defense. To further explore the impact of $\mathrm{ZnO} \mathrm{NPs}$ on macrophages and immune defense, we measured the level of macrophages $\mathrm{NO}$ production after 28 days treatment. As shown in figure 4, and Table 5, a significant decrease in NO level occurred after administration 50 of $\mathrm{ZnO} \mathrm{NPs}, \mathrm{mg} / \mathrm{kg}$ b.w. However, there was no substantial difference of $\mathrm{NO}$ level in $\mathrm{ZnO}$ NPs, $5 \mathrm{mg} / \mathrm{kg}$ b.w fed Balb/c mice as compared with the control. This decrease may result from more reactive oxygen species generation resulting in decreased iNOS activity (Kim et al., 2015).

\section{Phagocytosis assay}

Because ZnO NPs show cytotoxic effect via enhancing oxidative stress, which may cause cell apoptosis; we evaluated the phagocytosis activity of macrophages. Balb/c mice were treated with $\mathrm{ZnO}$-NPs. Our result showed that treating mice with $\mathrm{ZnO}$ NPs $(5.0 \mathrm{mg} / \mathrm{kg}$ ) enhanced phagocytic activity. However, phagocytic activity significantly decreased in mice treated with $\mathrm{ZnO}$ NPs $(50 \mathrm{mg} / \mathrm{kg})$ (Figure 7. Higher dose of Zinc oxide nanoparticle produce more free radicals leading to oxidative stress of immune cells (Lin et al, 2014). As shown in Figure 5 and Table 6 . 
Table.1 Particle characterization of ZnO NPs. Size and structure was determined by DLS and high resolution transmission electron microscope (HR-TEM) Tecnai G2 20 twin

\begin{tabular}{|c|c|c|}
\hline Characterization & $\begin{array}{c}\text { Mean diameter Size (nm) in } \\
\text { MilliQ water }\end{array}$ & $\begin{array}{c}\text { Crystalline } \\
\text { structure }\end{array}$ \\
\hline $\begin{array}{c}\text { Manufacture } \\
\text { size }\end{array}$ & 25.00 & spherical \\
\hline DLS & 52.8 & spherical \\
\hline HR-TEM & $25-30$ & spherical \\
\hline
\end{tabular}

Table.2 Different experimental groups and treatment (28 day) to Balb/c mice

\begin{tabular}{|c|c|}
\hline Groups & Treatment \\
\hline Control & Rivers osmosis (RQ) Drinking water @ 300 $\mu \mathrm{l} /$ mice \\
\hline ZnO NPs 5 & $5.0 \mathrm{mg} / \mathrm{kg} \mathrm{b.w} \mathrm{ZnO} \mathrm{NPs} \mathrm{@300} \mu 1 / \mathrm{mice}$ \\
\hline ZnO NPs 50 & $50 \mathrm{mg} / \mathrm{kg}$ b.w ZnO NPs @300 $\mu 1 / \mathrm{mice}$ \\
\hline
\end{tabular}

Table.3 Cytotoxicity of ZnONP on macrophages viability by MTT assay

\begin{tabular}{|c|c|}
\hline Treatment group & Viability (\%) \\
\hline Control & $100 \pm 0.0$ \\
\hline ZnONP5 $(\mathbf{5 . 0} \mathbf{~ m g / k g )}$ & $128.9 \pm 9.1$ \\
\hline ZnONP 50(50 $\mathbf{~ m g / k g ) ~}$ & $102.9 \pm 8.1$ \\
\hline
\end{tabular}

$. * P<.05$ and. $* * P<.01$ (mean \pm standard error of mean (SEM) and were analysed using one way ANOVA for cell viability)

Table.4 Cytotoxicity of ZnONPs s on macrophages viability by WST assay

\begin{tabular}{|c|c|}
\hline Treatment group & Viability (\%) \\
\hline Control & $100 \pm 0.0$ \\
\hline ZnONP5 $(\mathbf{5 . 0} \mathbf{~ m g / k g})$ & $124 \pm 18$ \\
\hline ZnONP50 $(\mathbf{5 0} \mathbf{~ m g} / \mathbf{k g})$ & $86 \pm 1.29$ \\
\hline
\end{tabular}

$. * P<.05$ and. $* * P<.01$ (mean \pm standard error of mean (SEM) and were analysed using one way ANOVA for cell viability) 
Table.5 Effect of ZnONPs on Nitric oxide production by macrophages

\begin{tabular}{|c|c|}
\hline Treatment group & Nitric Oxide conc.(n.mole) \\
\hline Control & $148.33 \pm 5.67$ \\
\hline ZnONP5(5.0 $\mathbf{~ m g / k g ) ~}$ & $180 \pm 21$ \\
\hline ZnONP50(50 $\mathbf{~ m g / k g ) ~}$ & $55 \pm 18.1$ \\
\hline
\end{tabular}

$* P<.05$ and. $* * P<.01$ (mean \pm standard error of mean (SEM) and were analysed using one way ANOVA for nitric oxide production)

Table.6 Effect of ZNFs on phagocytosis of macrophages (\%)

\begin{tabular}{|c|c|}
\hline Treatment group & Phagocytosis $(\boldsymbol{\%})$ \\
\hline Control & $34.66 \pm 3.74$ \\
\hline $\begin{array}{c}\text { ZnONP5(5.0 } \\
\text { mg/kg) }\end{array}$ & $53.0 \pm 0.0$ \\
\hline $\begin{array}{c}\text { ZnONP50(50 } \\
\text { mg/kg) }\end{array}$ & $16.66 \pm 0.20$ \\
\hline
\end{tabular}

$* P<.05$ and. $* * P<.01$ (mean \pm standard error of mean (SEM) and were analysed using one way ANOVA for phagocytosis assays).
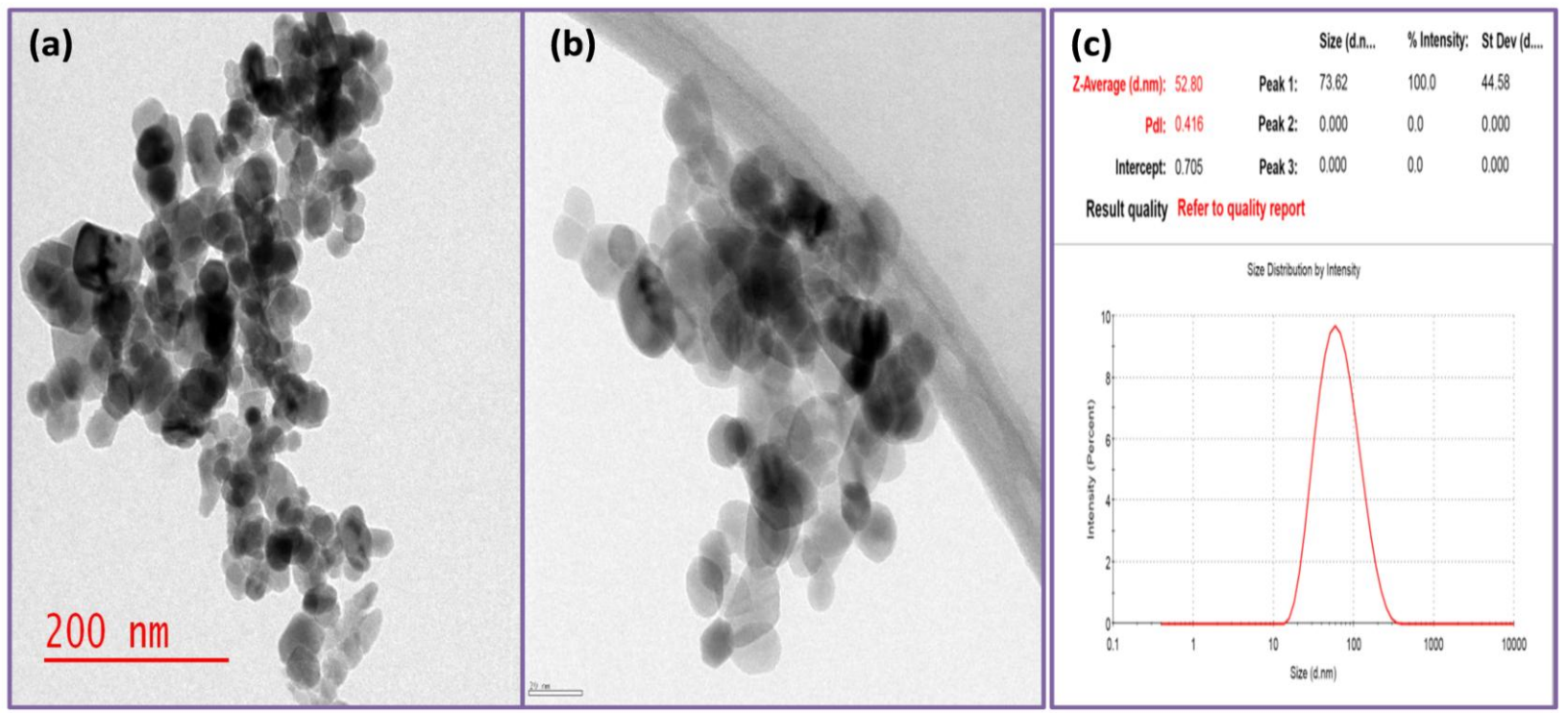

Fig1. (a) Particle size determined by high resolution transmission electron microscope (HRTEM) Tecnai G2 20 twin and shape (size 25-30nm (b) Manufacture TEM images of ZnO NPs $(100 \mu \mathrm{g} / \mathrm{mL})$ in Milli-Q water (size were $25 \mathrm{~nm}$ ) and (c) Z-average (d.nm) was shown $52.80 \mathrm{~nm}$. 


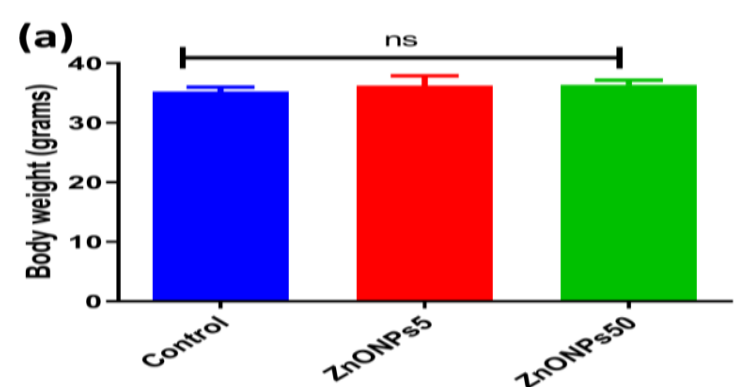

(c)

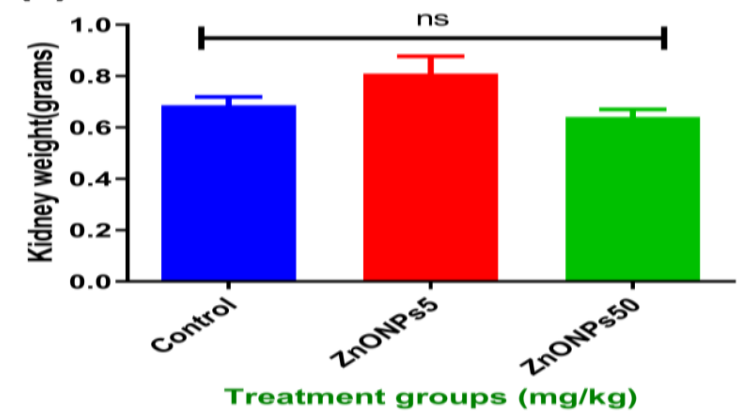

(b)

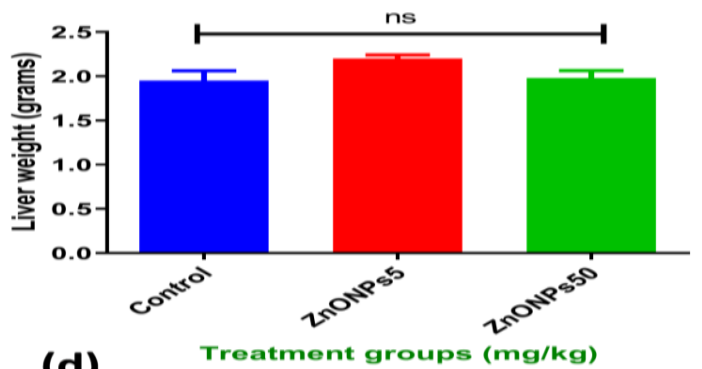

(d)

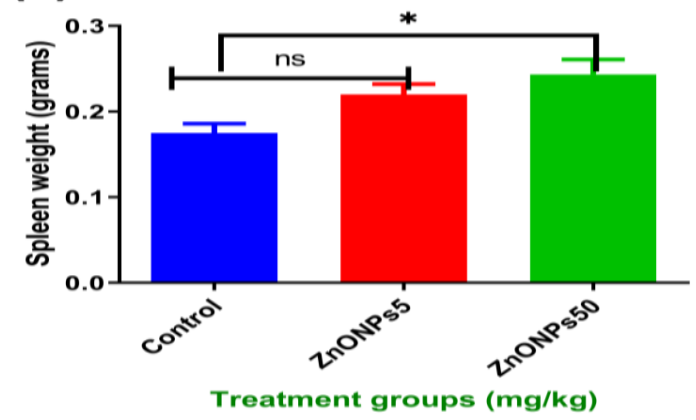

Fig2. Effect of different doses of zinc oxide nano particles on (a) Body weight, (b) Liver weight, (c) Kidney weight and (d) Spleen weight of Balb/c mice. Values are represented in mean \pm SEM, $(\mathrm{n}=6)$ and significantly different within the group $(* \mathrm{P}<0.05)$.

(a)

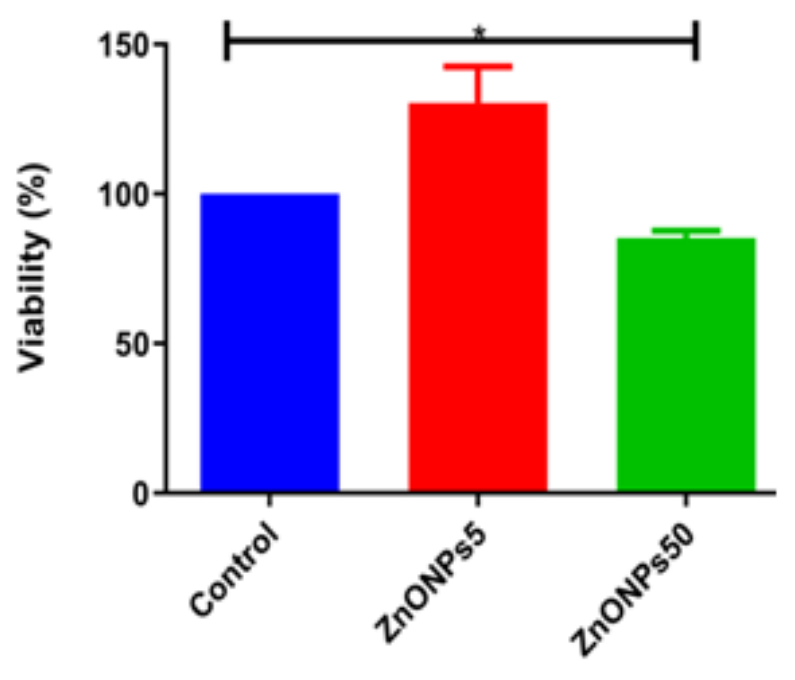

Treatment groups $(\mathrm{mg} / \mathrm{Kg})$ (b)

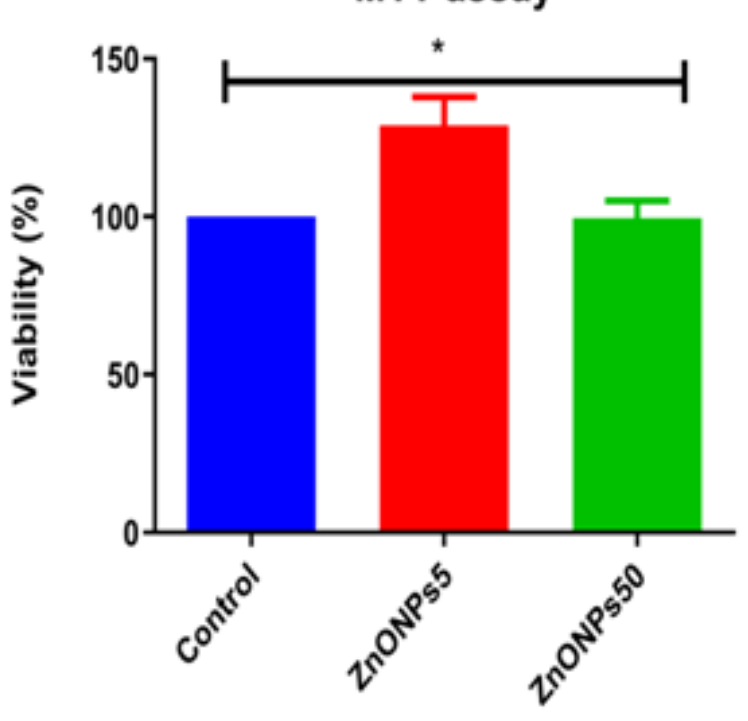

Treatment groups $(\mathrm{mg} / \mathrm{kg})$

Fig 3. Effect of increasing dose of zinc oxide nanoparticles on macrophage viability of Balb/c mice (a) Accessed by WST and (b) MTT assay. Values are represented in mean \pm SEM, $(n=6)$ and significantly different within the group $(* \mathrm{P}<0.05)$. 


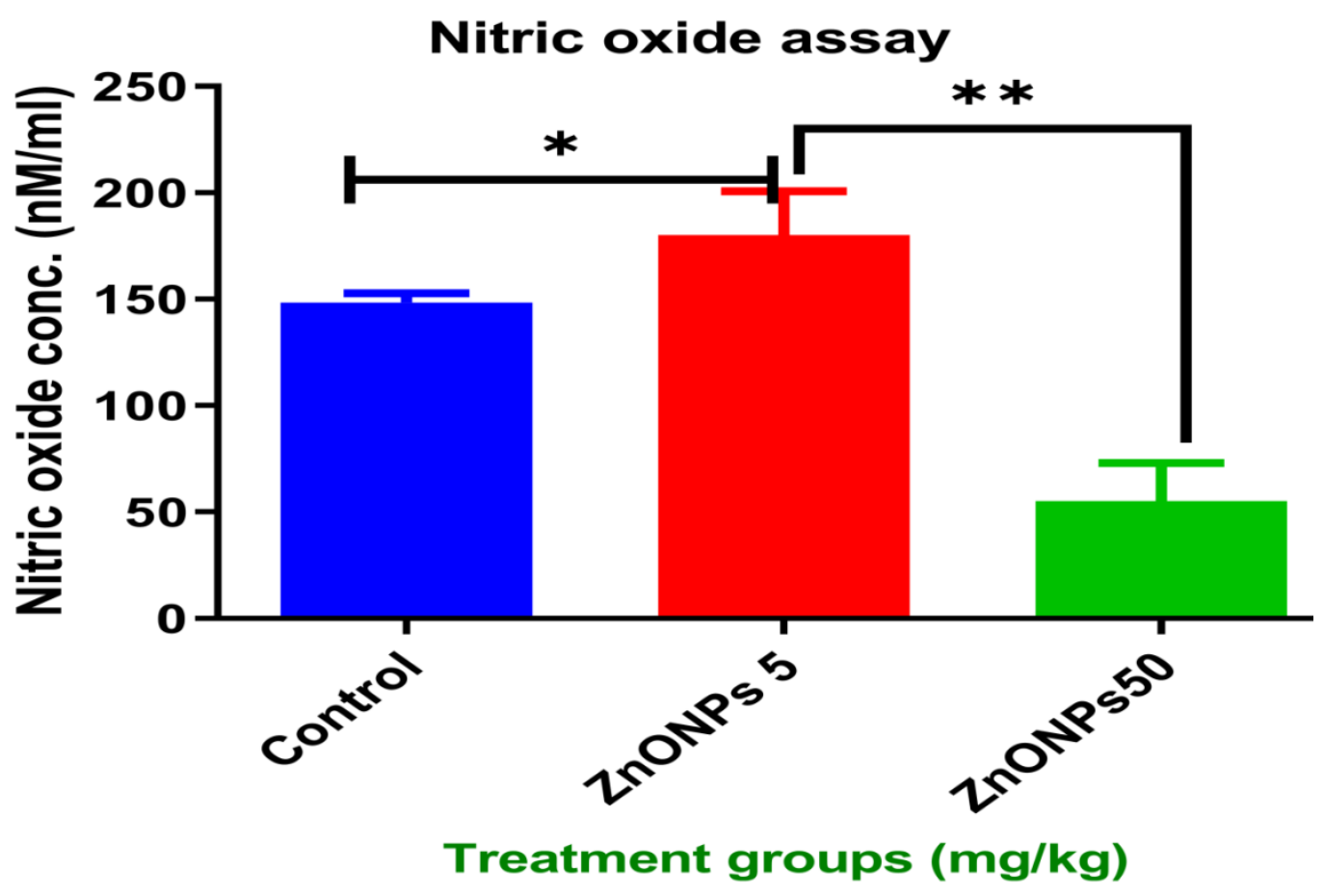

Fig 4. Nitric oxide production from macrophages affected by increasing doses of zinc oxide particles on of Balb/c mice. Values are represented in mean \pm SEM, $n=6$ and significantly different within the group $(* \mathrm{P}<0.05)$
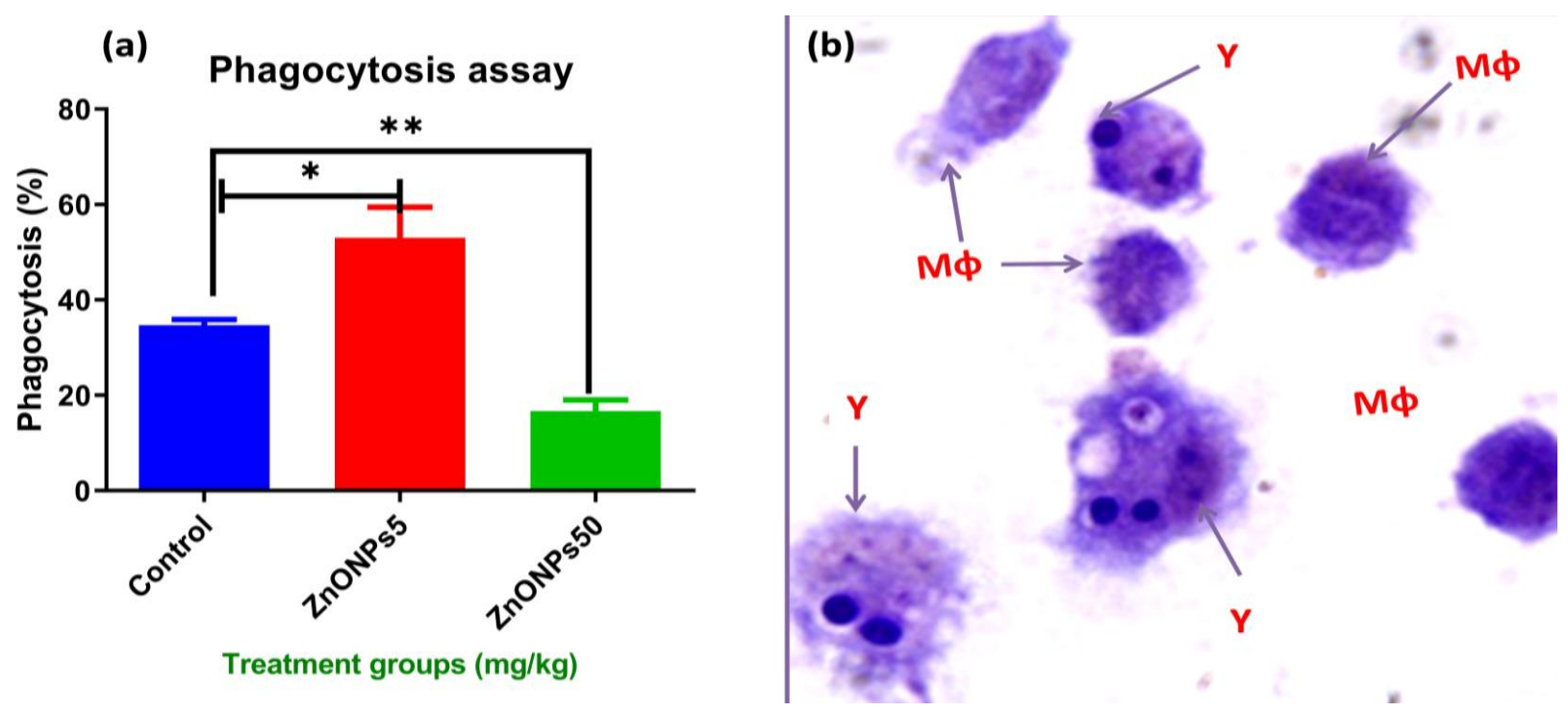

Fig5. Effect of increasing dose of zinc oxide nanofertilizer on macrophages phagocytic activity of Balb/c mice. Values are mean $\pm \mathrm{SEM}, \mathrm{n}=6$ and significantly different within the group $(* \mathrm{P}<$ $0.05)$. (a) Phagocytosis of yeast cells by peritoneal macrophages, (b) $\mathrm{M} \phi=$ macrophages, $\mathrm{Y}=$ Engulfed yeast cells at $1000 \mathrm{X}$ magnification. 


\section{Mechanism of ZnO NPs cytotoxicity}

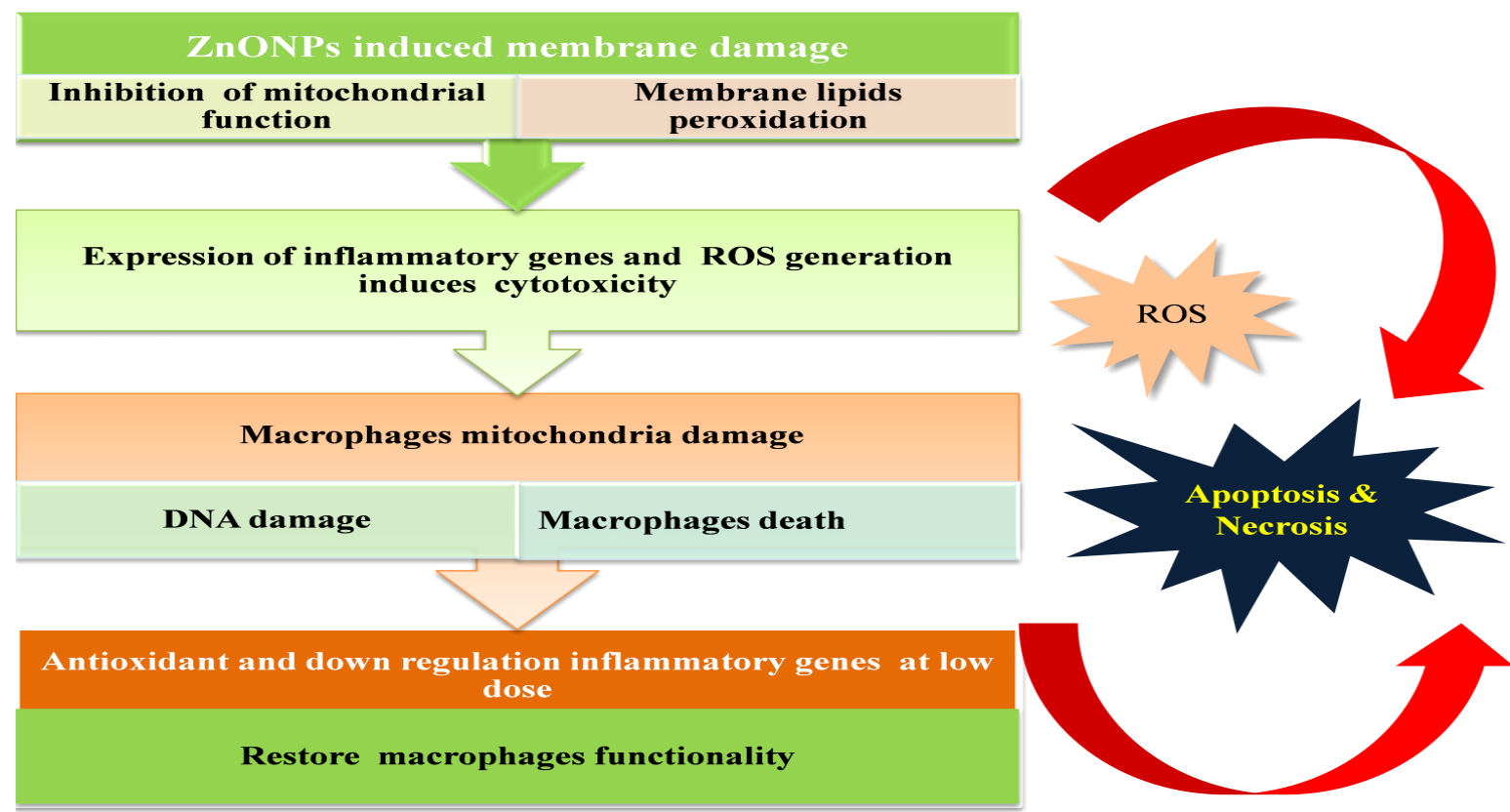

Fig.6 Proposed mechanism of ZnO NPs on the activities of immune cells

In this research, $\mathrm{ZnO}$ NPs at dose $5.0 \mathrm{mg} / \mathrm{kg}$, and $50 \mathrm{mg} / \mathrm{kg}$ alone. The effects induced by $\mathrm{ZnO}$ NPs included spleen enlargement, macrophages viability, nitric oxide production, peritoneal macrophages phagocytic activity statistically significant changes

In summary the adverse effect of $\mathrm{ZnO}$ NPs were tested in accordance with the OECD test guideline. Balb/c mice were orally treated with $\mathrm{ZnO}$ NPs for 28 days, with doses of 5 $\mathrm{mg} / \mathrm{kg} \mathrm{b.w}$ and $50 \mathrm{mg} / \mathrm{kg} \mathrm{b.w}$. The results of this study suggested that the administration of $50 \mathrm{mg} / \mathrm{kg}$ b.w ZnO NPs to mice had adverse effect on functionality of macrophages. Based on the results of this study, a dosage of 5 $\mathrm{mg} / \mathrm{kg}$ b.w of $\mathrm{ZnO}$ NPs was considered the no-observed-adverse-effect for immunotoxicity. There are different proposed mechanisms for $\mathrm{ZnO}$ NPs induced immunotoxicity. ROS generation and consequent OS are frequently observed and is the most discussed paradigm for NP toxicity (Nel., 2006). The Main mechanism of $\mathrm{ZnO}$
NPs is oxidative stress could be attributed to the combination of more than one phenomenon including: generation of ROS on the surface of particles (Park et al., 2011), physical interaction of $\mathrm{ZnO}$ NPs with the membrane wall leading to the deformation and rupture of membrane and dissolution and release of $\mathrm{Zn}^{2+}$ ions in the body ( $\mathrm{Li}$ et al., 2008).ROS generation mechanism varies according to NPs but exact mechanism are not understanding. Most important mechanism may be generation of ROS (relative oxygen species) by ZnONPs them self (Premanathan et al., 2011). NPs dissolve in body fluid and subsequent release of $\mathrm{Zn}^{2+}$ ions that lead to ROS mediated cell death. OS and hydroxyl radical $\left(\mathrm{OH}^{\prime}\right)$ is one of the main species responsible for macrophages damaging (Xia $\mathrm{T}$ et al., 2006). To keep the redox equilibrium at an intermediate level of OS, proinflammatory pathways are activated by $\mathrm{ZnO}$ NPs and increase in pro-inflammatory cytokines TNF- $\alpha$, IL-6, and IL-8. (Lipovsky et al., 2011), further decreased phagocytosis (Liu $\mathrm{H}$ et al., 2013). 
In the present research revealed a significantly decreased nitric oxide (NO) production in dose $50 \mathrm{mg} / \mathrm{kg}$ b.w treated mice while increase in $5.0 \mathrm{mg} / \mathrm{kg}$ b.w treated. ZnONPs induce general toxicity by increasing in the weight of spleen when orally exposed at a dose of $50 \mathrm{mg} / \mathrm{kg}$ body weight. ZnONPs could affect the functionality of innate immune cell macrophages. Nanoparticle interaction with the immune system and there mechanism shows in Figure 6.

In conclusion our research results shows that ZnONPs at a dose of $50 \mathrm{mg} / \mathrm{kg}$ b.w causes adverse effect on functionality of macrophages after 28 day exposes to $\mathrm{Balb} / \mathrm{c}$ Mice while $\mathrm{ZnONPs}$ at the dose $5 \mathrm{mg} / \mathrm{kg}$ b.w have immunomodulatory effects such kind effect.

\section{List of abbreviations}

Nanoparticles (NPs), Zinc Oxide nano particle ( $\mathrm{ZnO} \mathrm{NPs})$, instability $\left(\Delta \mathrm{H}_{\mathrm{ME}+}\right), \mathrm{EC}_{50}$ dose of nanoparticle that gives half-maximal response $\left(\mathrm{EC}_{50}\right)$, Reactive oxygen species (ROS), Reverse osmosis water (RO), Dulbecco's Modified Eagle's Medium Hams F-12 (DMEM), Fetal calf serum(FCS), Nitric oxide (NO), (3-(4, 5-Dimethylthiazol-2-yl)-2, 5-diphenyl-tetrazoliumbromide(MTT), Dimethyl sulfoxide (DMSO), standard error of the mean (SEM), zinc oxide nanoparticle 5 $\mathrm{mg} / \mathrm{kg}$ body weight (ZnONP5), zinc oxide nanoparticle $50 \mathrm{mg} / \mathrm{kg}$ body weight (ZnONP50).

\section{Acknowledgements}

The authors wish to thank the DirectorNational Dairy Research institute, Karnal (Haryana)-132001, India for the research grand to Jitendra Kumar for research and also thanks to Dr. Sadeesh E M and Dr.Chander datt, M.D mitra, for unconditional support and help during research.

\section{Conflict of Interest}

The authors declare no any competing financial interest in this study.

\section{References}

Barbuddhe, S.B., Malik, S.V.S. and Gupta, L.K., 1998. Effect of in vitro monocyte activation by Listeria monocytogenes antigens on phagocytosis and production of reactive oxygen and nitrogen radicals in bovines. Veterinary immunology and immunopathology, 64(2), pp.149159.

Dwivedi, P.D., Misra, A., Shanker, R. and Das, M., 2009. Are nanomaterials a threat to the immune system?. Nanotoxicology, 3(1), pp.19-26.

Glotter, E., 1991. Withanolides and related ergostane-type steroids. Natural product reports, 8(4), pp.415-440.

Gupta, A.P., 1996. Quantitative determination of withanferin-A in different plant parts of Withania somnifera by TLC densitometry. J. Medi. Aro. Plant Sci., 18, pp.788-790.

Kim, S.H., Heo, Y., Choi, S.J., Kim, Y.J., Kim, M.S., Kim, H., Jo, E., Song, C.W. and Lee, K., 2016. Safety evaluation of zinc oxide nanoparticles in terms of acute dermal toxicity, dermal irritation and corrosion, and skin sensitization. Molecular \& Cellular Toxicology, 12(1), pp.93-99.

Kumagai, K., Itoh, K., Hinuma, S. and Tada, M., 1979. Pretreatment of plastic Petri dishes with fetal calf serum. A simple method for macrophage isolation. Journal of immunological methods, 29(1), pp.17-25.

Kupchan, S.M., Doskotch, R.W., Bollinger, P., McPhail, A.T., Sim, G.A. and Renauld, J.S., 1965. The Isolation and Structural Elucidation of a Novel 
Steroidal Tumor Inhibitor from Acnistus arborescens1, 2. Journal of the American Chemical Society, 87(24), pp.5805-5806.

Li, N., Xia, T. and Nel, A.E., 2008. The role of oxidative stress in ambient particulate matter-induced lung diseases and its implications in the toxicity of engineered nanoparticles. Free Radical Biology and Medicine, 44(9), pp.1689-1699.

Li, N., Xia, T. and Nel, A.E., 2008. The role of oxidative stress in ambient particulate matter-induced lung diseases and its implications in the toxicity of engineered nanoparticles. Free Radical Biology and Medicine, 44(9), pp.1689-1699.

Li, N., Xia, T. and Nel, A.E., 2008. The role of oxidative stress in ambient particulate matter-induced lung diseases and its implications in the toxicity of engineered nanoparticles. Free Radical Biology and Medicine, 44(9), pp.1689-1699.

Lipovsky, A., Nitzan, Y., Gedanken, A. and Lubart, R., 2011. Antifungal activity of $\mathrm{ZnO}$ nanoparticles - the role of ROS mediated cell injury. Nanotechnology, 22(10), p.105101.

Liu, H., Yang, D., Yang, H., Zhang, H., Zhang, W., Fang, Y., Lin, Z., Tian, L., Lin, B., Yan, J. and Xi, Z., 2013. Comparative study of respiratory tract immune toxicity induced by three sterilisation nanoparticles: silver, zinc oxide and titanium dioxide. Journal of hazardous materials, 248, pp.478-486.

Lundqvist, M., Stigler, J., Cedervall, T., Berggård, T., Flanagan, M.B., Lynch, I., Elia, G. and Dawson, K., 2011. The evolution of the protein corona around nanoparticles: a test study. ACS nano, 5(9), pp.7503-7509.

Lynch, I. and Dawson, K.A., 2008. Proteinnanoparticle interactions. Nano today,
3(1-2), pp.40-47.

Meng, F., Cheng, R., Deng, C. and Zhong, Z., 2012. Intracellular drug release nanosystems. Materials today, 15(10), pp.436-442.López-Moreno, M. L., de la Rosa, G., Hernández-Viezcas, López-Moreno, M.L., de la Rosa, G., Hernández-Viezcas, J.Á., CastilloMichel, H., Botez, C.E., PeraltaVidea, J.R. and Gardea-Torresdey, J.L., 2010. Evidence of the differential biotransformation and genotoxicity of $\mathrm{ZnO}$ and $\mathrm{CeO} 2$ nanoparticles on soybean (Glycine max) plants. Environmental science \& technology, 44(19), pp.7315-7320.

Miranda, K.M., Espey, M.G. and Wink, D.A., 2001. A rapid, simple spectrophotometric method for simultaneous detection of nitrate and nitrite. Nitric oxide, 5(1), pp.62-71.

Mirjalili, Mohammad Hossein, Elisabeth Moyano, Mercedes Bonfill, Rosa M. Cusido, and Javier Palazón. "Steroidal lactones from Withania somnifera, an ancient plant for novel medicine." Molecules 14, no. 7 (2009): 23732393.

Misra, L., Mishra, P., Pandey, A., Sangwan, R.S., Sangwan, N.S. and Tuli, R., 2008. Withanolides from Withania somnifera roots. Phytochemistry, 69(4), pp.1000-1004.

Mosmann, T., 1983. Rapid colorimetric assay for cellular growth and survival: application to proliferation and cytotoxicity assays. Journal of immunological methods, 65(1-2), pp.55-63.

Nel, A., Xia, T., Mädler, L. and Li, N., 2006. Toxic potential of materials at the nanolevel. science, 311 (5761), pp.622627

Park, S.J., Park, Y.C., Lee, S.W., Jeong, M.S., Yu, K.N., Jung, H., Lee, J.K., Kim, J.S. and Cho, M.H., 2011. Comparing 
the toxic mechanism of synthesized zinc oxide nanomaterials by physicochemical characterization and reactive oxygen species properties. Toxicology letters, 207(3), pp.197203.

Peng, X.H., Qian, X., Mao, H. and Wang, A.Y., 2008. Targeted magnetic iron oxide nanoparticles for tumor imaging and therapy. International journal of nanomedicine, 3(3), p.311.

Perdigon, G., De Macias, M.E., Alvarez, S., Oliver, G. and de Ruiz Holgado, A.A., 1986. Effect of perorally administered lactobacilli on macrophage activation in mice. Infection and immunity, 53(2), pp.404-410.

Premanathan, M., Karthikeyan, K., Jeyasubramanian, K. and Manivannan, G., 2011. Selective toxicity of $\mathrm{ZnO}$ nanoparticles toward Gram-positive bacteria and cancer cells by apoptosis through lipid peroxidation. Nanomedicine: Nanotechnology, Biology and Medicine, 7(2), pp.184192.

Puzyn, T., Rasulev, B., Gajewicz, A., Hu, X., Dasari, T.P., Michalkova, A., Hwang, H.M., Toropov, A., Leszczynska, D. and Leszczynski, J., 2011. Using nano-QSAR to predict the cytotoxicity of metal oxide nanoparticles. Nature nanotechnology, 6(3), p.175.

Rico, Cyren M., Sanghamitra Majumdar, Maria Duarte-Gardea, Jose R. PeraltaVidea, and Jorge L. GardeaTorresdey. "Interaction of nanoparticles with edible plants and their possible implications in the food chain." Journal of agricultural and food chemistry 59, no. 8 (2011): 34853498.

Wang, J., Zhou, G., Chen, C., Yu, H., Wang, T., Ma, Y., Jia, G., Gao, Y., Li, B., Sun, J. and Li, Y., 2007. Acute toxicity and biodistribution of different sized titanium dioxide particles in mice after oral administration. Toxicology letters, 168(2), pp.176-185.

Xia, T., Kovochich, M., Liong, M., Mädler, L., Gilbert, B., Shi, H., Yeh, J.I., Zink, J.I. and Nel, A.E., 2008. Comparison of the mechanism of toxicity of zinc oxide and cerium oxide nanoparticles based on dissolution and oxidative stress properties. ACS nano, 2(10), pp. 2121-2134.

Yoo, J.W., Irvine, D.J., Discher, D.E. and Mitragotri, S., 2011. Bio-inspired, bioengineered and biomimetic drug delivery carriers. Nature reviews Drug discovery, 10(7), p.521.

\section{How to cite this article:}

Jitendra Kumar, Kavita Rani, Sonia Sangwan, M.D Mitra, H.B Singh, H.P Yadav and Gautam Kaul. 2018. Zinc Oxide Nano Particle (ZNO NPs) and Innate Immunity: New Perspectives in Immunotoxicity. Int.J.Curr.Microbiol.App.Sci. 7(07): 1865-1878.

doi: https://doi.org/10.20546/ijcmas.2018.707.222 